survey was being conducted. This hampered the normal flow of data between observer and recorder and may have accounted for the imbalance between east and west. Further distractions included the inconsiderate appearance of an occupant in the middle of a site recording and a large poster requesting information on Tiga the cat was nearly mistaken for a shoddy plate.

At the high frontier of human endeavour there will always be many more questions raised than can be answered satisfactorily. We hope, however, that this study in its own small way will help to stimulate and encourage further work into this unusual though fascinating field of medical research.

We should like to thank the staff of the Medical Illustration Department of the Institute of Laryngology and Otology for their patient assistance.

\section{References}

1 Weinreb B, Hibbert C. The London encyclopaedia. London: Macmillan, 1983. 2 Bebbington G. London street names. London: Batsford, 1972.

3 Scott Stevenson R. Goodbye Harley Street. London: Christopher Johnson, 1954.

4 Anonymous. The recession from Harley Street [Editorial]. Br Med F 1952;ii: 1407.

The Royal National Throat, Nose and Ear Hospital, Gray's Inn Road, London WC1X 8DA

RICHARD C BICKERTON, FRCS, locum senior registrar

Kent and Sussex Hospital, Tunbridge Wells, Kent

CATHERINE M MILTON, BSC, FRCS, consultant otolaryngologist

Correspondence to: $\mathrm{Mr}$ Bickerton.

\title{
Living with a marathon runner
}

\author{
JUNE M CROWN
}

Our 22 year marriage was put under its most severe strain when one evening at the theatre, just as the play was about to begin, my husband whispered, "I heard this morning that I have got into the London Marathon." My enforcedly muted response combined alarm, anxiety, and disbelief. He was a jogger-regular two and a

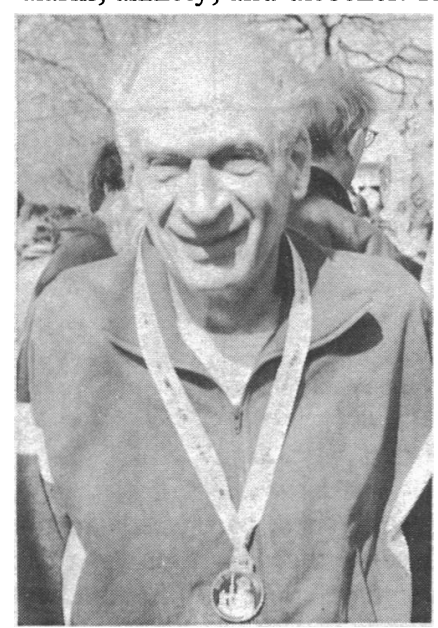
half miles a day - and had applied twice already for the marathon. The polite rejection slips that he had received then had lulled me into assuming that the computer was on my side. Surely it realised that he was beyond the age when any sensible person would attempt his first marathon? The letter from the organisers, however, was unambiguousacceptance, congratulations, and sensible advice.

For a while we were all rather secretive about it. My husband thought that it could be kept within the family and that his eccentricity need not be revealed to the world. It soon became clear, however, that selection brings with it the opportunity, which rapidly develops into the responsibility, to raise money for charity. He chose the Mental Health Foundation, with which he had been associated for some time and which reflects his professional interests.

The sponsorship provided a valuable spur to the training programme. Going out in the icy mornings of February and March was slightly easier when it was associated with the "the good cause" and "not letting the side down." At weekends he gradually raised the milage. Twenty one miles in the teeth of a gale along Brighton sea front and 25 miles in somewhat better conditions in London raised his confidence and reduced my anxiety.

The marathon weekend itself is already part of the Crown family folklore. On Saturday we went to Parsifal. I had doubts about the wisdom of this, but was swayed by the undoubted truth of my son's

Bloomsbury Health Authority, London WC1E 6DB

JUNE M CROWN, MB, FFCM, district medical officer
statement-"There is no other way you will get Dad to sit down for six hours."

Marathon day started wet and cold. We drove to Charing Cross Station, where special trains were taking the runners to the start at Greenwich. In their uniforms of track suits and trainers, clutching their sports bags, and with a nervous camaraderie, the participants had something of the air of soldiers on a troop train off to France in the 1940s.

I went home to the television set and the sight of thousands of people in the pouring rain embarking on the great adventure. Somehow I passed two and a half hours in totally aimless activity before going back into London to take up a position along the Embankment. I knew that there were 20000 participants but had never realised what that meant in terms of the apparently never ending procession of runners. My confidence in my husband's ability to complete the course began to be eroded as some (often much younger) participants hobbled past, clearly unlikely to manage the last two miles. What would I do if he looked like that? As the time approached when we expected him I became even more worried. What would I do if he did not appear at all? Perhaps he had fallen on the cobbles or been run down by a wheelchair. At last he appeared, clearly fine and jogging well. The relief was unbelievable. After that the walk over Waterloo Bridge and the meeting among thousands under the trees in Jubilee Gardens were jubilant.

I learnt a great deal from this episode in our lives. For example, I feel I now know what it is like to be a man during labour, observing an event to which you have an enormous emotional commitment, for which you want to give complete support to a loved one, and which you can do almost nothing at all to influence.

We both think that the marathon brings out the best in people. My husband found his fellow participants friendly and concerned for one another's welfare. The people lining the streets were unfailingly cheerful and supportive and played a real, almost tangible, part in keeping him going as he "hit the wall." People showed great generosity in sponsoring and genuine warmth in congratulating him on finishing the run.

He promised me at the outset that this would be a "once in a lifetime" event, the fulfilment of a secret personal ambition. I am beginning to wonder, though, whether the happiness which the marathon generates does not produce some kind of contagion. It even crossed my mind that the computer might be interested in a husband and wife team next year. But with luck, the endorphin levels will have fallen by the time that the application forms have to go in.

Published by the Proprietors, THE BRITISH MEDICAL ASSOCIATION, Tavistock Square, London WC1H 9JR, and printed in Great Britain by Pulman Web Offset Limited, Member of BPCC Group. Typesetting by Bedford Typesetters Limited, Bedford. 